\title{
Green Manufacturing Practices (GMP) Framework For Local Small and Medium Enterprises (SME) In Johor, Malaysia: A Review On Enablers And Barriers and Preliminary Findings on Critical Factors
}

\author{
Nur Syuhada binti Zakaria ${ }^{1}$ and Sulaiman bin Haji Hasan ${ }^{2}$ \\ ${ }^{1,2}$ Faculty of Mechanical and Manufacturing Engineering, Manufacturing and Industrial Department \\ Universiti Tun Hussein Onn Malaysia, 86400, Batu Pahat, Johor \\ ${ }^{1}$ gd150090@siswa.uthm.edu.my \\ 2sulaiman@uthm.edu.my
}

\begin{abstract}
This study focuses mainly on Green Manufacturing Practices (GMP) for local small medium enterprises (SME) in the state of Johor, Malaysia. This review includes the enablers and barriers in GMP from previous studies in local and international contexts. Critical factors that affect GMP were also highlighted. It also points out relationships between enablers and barriers of GMP and measures the strengths and weaknesses of GMP. This paper also reviewed the implementation practices, issues and norms. The reviewed outcome will be a guide to formulate an effective framework for GMP in SME.
\end{abstract}

Keyword- Green manufacturing practices, small and medium enterprises (SME), Enablers and Barriers, Critical factors

\section{INTRODUCTION}

There are many interpretations of green manufacturing and all of it convey similar meanings. Generally, green manufacturing (GM) can be defined as the three "R"s which are remanufacture, reduce, and reuse/recycle [1] which include activities such as reducing hazardous waste volume, minimizing coolant consumption while machining and calculating proper energy mixes to ensure a sustainable energy source [2]. GMP is one of the initiatives to improve environmental concern and awareness. It also drives manufacturers [3] including SME (small and medium enterprises) to adopt GMP. However, the way SME implement GMP is differ from those of large enterprises since SME lack organization, eco-knowledge and environmental factors [3]. In 2012, there was a review by Universiti Teknologi Mara (UTM) researchers about green supply chain management (GSCM) in the geographical region [4]. The paper mentioned that there is an indication that suitable regulation and policies can be set by government to help small companies to practice GM.

\section{ENABLERS AND BARRIERS IN GMP THAT INFLUENCES SME}

The environmental performance of the SME is mostly driven by the intention of company owners. SME is defined by a number of criteria such as size, age, organizational structure, location, number of employees, sales volume [3],[5]. Since SME play a crucial role in a nation's economic growth, it is imperative to identify the enablers and barriers which will motivate or hinder the implementation of green manufacturing practices in SME which forms the main motivation of intended work [3]. Table 1 shows the list of enablers that influence the green manufacturing practices from previous studies. Enablers and barriers will provide a clear guide in ensuring the success in the implementation of GMP. It will save cost, time and resources .Table 2 shows the list of barriers mentioned in the reviewed literature. From the author Raja Ariffin Raja Ghazilla et al. [3] has found out the enablers was legislation that explaining about voluntary GMP regulations and standards (e.g. ISO 14001) and eco labelling, eco-knowledge which is availability of comprehensive training and education in GMP and innovation that covered about organizational beliefs of innovation opportunities through GMP. Financial benefit was mentioned by K. Govindan et al, [1]; Dornfeld et al, [2]; Wu and Wirkkala [6]; Searcy et al.[7]; Chin et al.[8]; Agan et al, [9] that briefing about the economic crisis forces SMEs to adapt GM because GM practices impact the optimal use of resources and energy usage which increase the financial benefits of the firm. From author K. Govindan et al, [1]; Dornfeld et al, [2]; Wu and Wirkkala [6] stated that environmental conservation is of the enablers for the GMP that covered about the depletion of natural resources and concerns on environmental conservation motivate GM implementation. K. Govindan et al, [1]; Dornfeld et al, [2]; Routroy [10]; Tseng et al.[11]; Zhu and Sarkis [12] mentioned that green innovation is a due to the paramount importance of green activities, green innovations are emerging in the current practices which force manufacturers to adopt new sustainable tactics. Another enablers were finding out by the author T.K. Eltayeb et 
al. [13]; Carter et al. [14] mentioned about green purchasing that covered about environmentally-conscious purchasing practices that aim at ensuring that purchased items meet environmental objectives of the firm such as reducing or eliminating hazardous items. Reverse logistics was a process of the return or take-back of a product or packaging, after use, from customers or suppliers for the purpose of reuse, recycling, reclamation of materials from the product or packaging, or a safe refill of products that was found out by T.K. Eltayeb et al. [13]; Carter and Ellram [15]. Last point for enablers was an environmental outcomes which are the actual impacts of green supply chain initiatives on the environmental performance of a firm such as compliance with environmental standards, reductions in air emissions, resource consumption, and consumption of hazardous materials that was stated by T.K. Eltayeb et al. [13]. Knowledge of barriers will enable effective precautions to be taken in implementing GMP. In certain cases total avoidance of the situation may be taken.

For the barriers, author Raja Ariffin Raja Ghazilla et al. [3] was found out organizational, eco-knowledge and business environment. Weak organizational structure to support the GMP lack empowerment to support GMP and improper communication structures to support GMP. For the eco-knowledge, the author was stated lack of GMP knowledge about eco-knowledge and difficulties in obtaining GMP information for potential improvements. Weak market positions for GMP-based products/processes and lack of influences on GMP strategic adaptation competence against changes in SME. K. Govindan et al, [1]; Dornfeld et al, [2]; Wu and Wirkkala [6]; Searcy et al.[6]; Chin et al.[8]; Agan et al, [9] mentioned that the economic urge and crisis pressure SME to adapt GM because GM practices impact the optimal use of resources and energy usage which increase the financial benefits of the firm. Depletion of natural resources and concerns of environmental conservation motivate GM implementation state by K. Govindan et al, [1]; Dornfeld et al, [2]; Wu and Wirkkala [6]. K. Govindan et al, [1]; Dornfeld et al, [2]; Routroy [10]; Tseng et al.[11]; Zhu and Sarkis [12] was mentioned that green innovation due to the paramount importance of green activities, green innovations are emerging in the current practices which force the manufacturers to adopt new sustainable tactics. Unfortunately, there is no real drive for innovation, especially concerning green practices. Green purchasing covered the Environmentally-conscious purchasing practice that aims at ensuring that purchased items meet environmental objectives of the firm such as reducing or eliminating hazardous items stated by T.K. Eltayeb et al. [13]; Carter et al. [14]. Author T.K. Eltayeb et al. [13]; Carter and Ellram [15] mentioned that no proper reverse logistics process of the return or take-back of a product or packaging, after use, from customers or to suppliers for the purpose of reuse, recycling, reclamation of materials from the product or packaging, or safe refill of product. T.K. Eltayeb et al. [13] said that the actual impacts of green supply chain initiatives on environmental performance of a firm such as compliance to environmental standards, reductions in air emissions, resource consumption and consumption of hazardous materials for environmental outcomes. Last point for barriers from previous literature was a society influences which is society with low green attitudes and lack of awareness on green products/processes among that stated by Raja Ariffin Raja Ghazilla et al.[3]. The enablers and barriers were selected according to the relevance in SME. These factors are critical factors discussed in most literature related to GMP.

\section{III.GREEN MANUfaCtURING PraCtices (GMP) FRAMEWORK}

In 2013, Minhaj in his research [16] stated that by identifying the weak areas through the barriers of GMP, a company may use the knowledge to formulate improvement plans for GM implementation [16]. This research was conducted to find the factors that affect green manufacturing practices as well as enablers and barriers that influence the factors and framework to guide the SME to implement GMP. Table 3 shows the critical factors and detailed description for each factor. The authors formulated those critical factors by combining the enabler and barriers that have been set by authors reviewed previously.

TABLE 1. Critical factors and its description

\begin{tabular}{|c|c|c|}
\hline No & Critical factor & Description \\
\hline 1 & Organization style & $\begin{array}{l}\text { - Implementation of ISO } 14001 \text { and Environmental Management } \\
\text { System (EMS) } \\
\text { - Environmental issues and strategic planning [17]. } \\
\text { - Involvement in decision-making process for implementing green } \\
\text { concepts [18]. } \\
\text { - To integrate environmental concerns into policies, plans, programs } \\
\text { and projects for economic and social development [18]. }\end{array}$ \\
\hline 2 & Business environment & $\begin{array}{l}\text { - Commitment from various business stakeholders } \\
\text { - Depletion of natural resources and concerns regarding environment } \\
\text { conservation } \\
\text { - Finance organization culture, skills and expertise [19],[20] }\end{array}$ \\
\hline
\end{tabular}




\begin{tabular}{|c|c|c|}
\hline 3 & Eco-knowledge & $\begin{array}{l}\text { - Focus on the commitment and responsibilities of green } \\
\text { manufacturing and awareness about reverse logistics [18],[1]. } \\
\text { - To protect and conserve critical ecological systems and resources } \\
\text { such as invaluable natural and man-made heritage which are } \\
\text { essential for life support, livelihoods, economic growth, and a broad } \\
\text { conception of human well-being[18]. } \\
\text { - Availability of comprehensive training and education in GMP }\end{array}$ \\
\hline 4 & Society & $\begin{array}{l}\text { - It mainly focuses on the customer requirement while designing the } \\
\text { product [18]. } \\
\text { - Knowledge and green attitude of the society [3]. } \\
\text { - } \text { Customer involvement and satisfaction [21],[20] }\end{array}$ \\
\hline 5 & $\begin{array}{l}\text { Supply chain } \\
\text { management }\end{array}$ & $\begin{array}{l}\text { - Involves suppliers, manufacturers, customers and reverse logistics } \\
{[18] .} \\
\text { - Focuses on green purchasing, internal environmental operation } \\
\text { management and green logistics [18]. }\end{array}$ \\
\hline 6 & Technology network & $\begin{array}{l}\text { - Analyzing technological outcomes to determine its suitability for } \\
\text { green manufacture [18]. } \\
\text { - Technology innovation [20]. }\end{array}$ \\
\hline
\end{tabular}

This six of critical factor will be a guide to build the framework of GMP for SME. The researcher intends to conduct a research about GMP in SME in the state of Johor. The research will focus on the selected factors presented above. The outcome will provide a guide for the practices in the form of a framework. This framework will be user-friendly, simple and practical.

\section{IV.CONCLUSION}

The paper has identified enablers and barriers of GMP implementation by reviewing the current literature. The tabulation of the factors leading to derivation of critical factors contains the key factors which are important for the formulation of the framework. A set of questionnaire and survey will build from the six critical factors and will contribute to the SME. The SME that will be studied are located in the state of Johor. The framework will determine the best practices that should be adopted to implement a successful GMP.

\section{ACKNOWLEDGEMENTS}

The author would like to acknowledge and thank the Centre for Graduate Studies, Universiti Tun Hussein Onn Malaysia and Postgraduate Research Grant (GPPS) for sponsoring this project.

\section{REFERENCES}

[1] Kannan Govindan, Ali Diabat and K.Madan Shankar. Analyzing the drivers of green manufacturing with fuzzy approach. Journal of Cleaner Production., 96,182-193, 2015

[2] Dornfeld,D., Yuan,C., Diaz,N., Zhang,T., Vijayaraghavan. Introduction to Green Manufacturing. In: Green Manufacturing. Springer US. pp. 1-23, 2013

[3] Raja Ariffin Raja Ghazilla, Novita Sakundarini, Salwa Hanim Abdul-Rashid, Nor Syakirah Ayub, Ezutah Udoncy Olugu and S.Nurmaya Musa. Drivers and Barriers analysis for green manufacturing practices in Malaysian SMEs: A Preliminary Findings. Procedia CIRP Global Conference on Sustainable Manufacturing.,2015, 26,658-663

[4] Rahman, S.-u., A comparative study of TQM practice and organisational performance of SMEs with and without ISO 9000 certification. International Journal of Quality \& Reliability Management, 2001. 18(1): p. 35-49.

[5] Noor Aslinda Abu Seman, Norhayati Zakuan, Ahmad Jusoh and Mohd Shoki Md Arif. Green Supply Chain Management: A Review and Researches Direction. Int. Journal of Managing Value and Supply Chain.,Vol.3, No.1, 2012

[6] Wu , J., Wirkkala, M.T.. Firms’ motivations for environmental over compliance. Rev. Law Econ. (2009)5. 1

[7] Searchy, C., Morali, O., Karapetrovic, S., Wichuk, K., McCartney, D., McLeod, S., Fraser, D.,.Challenges in implementing a functional ISO 14001 environmental management system,. Int. J. Qual Reliab. Manag., 29(7),779-796, 2012

[8] Chin, K.S., Chiu, S., Tummala, V.M.R. An evaluation of success factors using the AHP to implement ISO 14001-based EMS. Int J. Qual. Reliab. Manag., 16(4),341-361, 1999

[9] Agan, Y., Acar, M.F Borodin, A.,. Drivers of environmental processes and their impact on performance; A study of Turkish SMEs., 51,23-33, 2013

[10] Routroy, S.,. Antecedents and drivers for green supply chain management implementation in manufacturing environment. Icfai Univ. J. Supply Chain Manag. VI (1), 2009

[11] Tseng, M.L, Wang, R., Antony, Chiu S.F., Geng, Y., Lin, Y.H.,.Improving performance of green innovation practices under uncertainly. J. Clean. Prod., 40,71-82, 2013

[12] Zhu, Q., Sarkis J.,. An inter-sectoral comparison of green supply chain management in China: drivers and practices. J. Clean. Prod. 14(5), 472-486, 2006

[13] Tariq K.Eltayeb, Suhaiza Zailani and T.Ramayah. Green supply chain initiatives among certified companies in Malaysia and environmental sustainability: Investigating the outcomes. Resources, Conservation and Recycling.,55,495-506, 2011

[14] Carter, C.R., Rogers, D.S. A framework of sustainable supply chain management: moving toward new theory. Int. J. Phys. Distrib. Logist. Manag, 38(5),360-387, 2008 
[15] Carter CR and Ellram LM. Reverse logistics: a review of the literature and framework for future investigation. Journal of Business Logistics.,19,85-102.

[16] Minhaj Ahemad.A.Rehman, R.R Shrivastava. and Rakesh.L Shrivastava. Validating Green Manufacturing (GM) Framework for Sustainable Development in an Indian Steel Industry. Uni. Journal of Mechanical Engineering.1(2), 49-61, 2013

[17] T. Ramayah, Osman Mohamad, Azizah Omar, Malliga Marimuthu and Jasmine Yeap Ai Leen. Green Manufacturing Practices and Performance among SMEs: Evidence from a Developing Nation. (2013)

[18] Swapnil V. Ghinmine and Dilip I. Sangotra. Implementation of Green Manufacturing in Industry - A case study. International Journal of Research in Engineering and Technology., 04,2319-1163, 2015

[19] Motwani Jaideep. “Critical factors and performance measures of TQM”. The TQM Magazine Volume 13, 4. Pp 292 -300, 2001

[20] Minhaj Ahemad. A.Rehman, R.R Shrivastava and Rakesh.L Shrivastava. Validating Green Manufacturing (GM) Framework for Sustainable Development in an Indian Steel Industry. Universal Journal of Mechanical Engineering., 1(2) 49-61, 2013

[21] Pius Achanga, Esam Shehab, Rajkumar Roy and Geoff Nelder. "Critical success factors for lean implementation within SMEs". Emerald 17, 2006

\section{Author Profile}

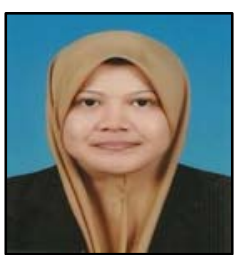

Nur Syuhada binti Zakaria was born on $9^{\text {th }}$ December 1990 in Kedah, Malaysia. She has obtained her Bachelor of Mechanical Engineering from Universiti Tun Hussein Onn Malaysia on 2015 and Diploma in Mechanical Engineering from Polytechnic Sultan Abdul Halim Mu'adzam Shah, Malaysia on 2011. Currently she is doing research on Green Manufacturing Practices (GMP) framework for local SMEs in Johor, Malaysia.

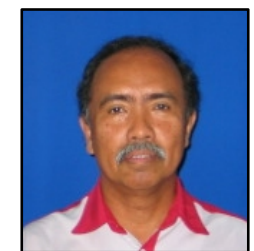

Sulaiman Haji Hasan is a Professor of Manufacturing Engineering at Universiti Tun Hussein Onn Malaysia, Batu Pahat, Johor. He passes diploma of education from Universiti Malaya, Degree of Production Engineering from University Birmingham, United Kingdom in 1980 and MSc in Advance Manufacturing at University Liverpool, United Kingdom in 1987. He then did Doctor of philosophy awarded by University Birmingham, United Kingdom in 1997. His career with Universiti Tun Hussein Onn Malaysia started in 2001 as a Dean of Faculty Engineering Technology and continued as Director at International Relation from 2003 until 2006. He then becomes the Dean of Mechanical and Manufacturing Engineering from 2006 to 2011. Some of his later paper Computerised Value Stream System (CVSS) to Reduce Waste in Lean Manufacturing Operation, Current Reverse Logistic for End of Life computer in Malaysia, A review on an employee empowered TQM practice, Internet Based Supply Chain Management for Local SMIs, Supply Chain Models, Application of it in Supply Chain Management, Application of soft system technology in Supply Chain Management, Application of knowledge based systems in supply chain management, Global Supply Chain framework and Supply Chain Re-engineering and he has 77 journal paper and his main research group is Advanced Manufacturing and Material Centre. 